\title{
Reducing the CP content in broiler feeds: impact on animal performance, meat quality and nitrogen utilization
}

\author{
P. Belloir ${ }^{1,2}$, B. Méda ${ }^{1 \dagger}$, W. Lambert ${ }^{2}$, E. Corrent ${ }^{2}$, H. Juin ${ }^{3}$, M. Lessire ${ }^{1}$ and S. Tesseraud ${ }^{1}$ \\ ${ }^{1}$ URA, INRA, 37380 Nouzilly, France; ${ }^{2}$ Ajinomoto Eurolysine S.A.S., F-75817 Paris Cedex 17, France; ${ }^{3}$ EASM, INRA, 17700 Saint-Pierre-d'Amilly, France
}

(Received 6 June 2016; Accepted 12 March 2017; First published online 2 May 2017)

\begin{abstract}
Reducing the dietary CP content is an efficient way to limit nitrogen excretion in broilers but, as reported in the literature, it often reduces performance, probably because of an inadequate provision in amino acids ( $A A)$. The aim of this study was to investigate the effect of decreasing the CP content in the diet on animal performance, meat quality and nitrogen utilization in growingfinishing broilers using an optimized dietary AA profile based on the ideal protein concept. Two experiments (1 and 2) were performed using 1-day-old PM3 Ross male broilers (1520 and 912 for experiments 1 and 2, respectively) using the minimum AA: Lys ratios proposed by Mack et al. with modifications for Thr and Arg. The digestible Thr (dThr): dLys ratio was increased from $63 \%$ to $68 \%$ and the dArg:dLys ratio was decreased from $112 \%$ to $108 \%$. In experiment 1, the reduction of dietary CP from $19 \%$ to $15 \%$ (five treatments) did not alter feed intake or BW, but the feed conversion ratio was increased for the $16 \%$ and $15 \%$ $C P$ diets ( $+2.4 \%$ and $+3.6 \%$, respectively), while in experiment 2 (three treatments: $19 \%, 17.5 \%$ and $16 \% C P$ ) there was no effect of dietary CP on performance. In both experiments, dietary CP content did not affect breast meat yield. However, abdominal fat content (expressed as a percentage of BW) was increased by the decrease in CP content (up to +0.5 and +0.2 percentage point, in experiments 1 and 2, respectively). In experiment 2, meat quality traits responded to dietary $\mathrm{CP}$ content with a higher ultimate $\mathrm{pH}$ and lower lightness and drip loss values for the low $C P$ diets. Nitrogen retention efficiency increased when reducing $C P$ content in both experiments (+3.5 points/CP percentage point). The main consequence of this higher efficiency was a decrease in nitrogen excretion (-2.5 $\mathrm{g} \mathrm{N} / \mathrm{kg} B W$ gain) and volatilization (expressed as a percentage of excretion: -5 points/CP percentage point). In conclusion, this study demonstrates that with an adapted AA profile, it is possible to reduce dietary CP content to at least $17 \%$ in growing-finishing male broilers, without altering animal performance and meat quality. Such a feeding strategy could therefore help improving the sustainability of broiler production as it is an efficient way to reduce environmental burden associated with nitrogen excretion.
\end{abstract}

Keywords: broiler, low-protein diet, performance, meat quality, environment

\section{Implications}

Broiler production is known to produce large amounts of ammonia, contributing to eutrophication and soil acidification. One efficient way to limit ammonia emission from manure is to decrease nitrogen excretion by broilers by lowering the dietary CP content. We investigated the consequences of such a decrease associated with a supplementation of amino acids (AA) on broiler performance, meat quality and nitrogen utilization during the growing-finishing phase. Using the ideal protein concept, reducing dietary CP content from $19 \%$ to $17 \%$ decreased nitrogen excretion and volatilization without negative consequences on animal performance or meat quality.

\footnotetext{
${ }^{\dagger}$ E-mail: bertrand.meda@inra.fr
}

\section{Introduction}

The environmental effects of livestock production are well described in the literature (Steinfeld et al., 2006; de Vries and de Boer, 2010; Gerber et al., 2013). The main environmental burden caused by broiler production is ammonia emission, responsible for water pollution (eutrophication) and soil acidification (Bouwman et al., 2002; Méda et al., 2011). Ammonia is emitted from the manure by the breakdown of undigested protein and uric acid. As reported by Méda et al. (2011), a possible way to decrease ammonia emission is to decrease nitrogen excretion by lowering the dietary CP content. Indeed, several studies have shown a reduction in nitrogen excretion by about $10 \%$ with a 1 percentage point decrease in the dietary CP content in broilers (Aletor et al., 2000; Bregendahl et al., 2002; Gomide et al., 2011). 
Formulation of low $\mathrm{CP}$ diets requires controlling the provision of indispensable AA, that is, Lys, Met (+ Cys), Thr, Val, Ile, Leu, Trp, Arg, Phe (+ Tyr) and His. In particular, the need for the first limiting indispensable AA can be satisfied by incorporating feed-grade AA. To balance the AA profile of the diet, practical formulation is generally based on an 'ideal AA profile' or 'ideal protein concept', for instance to maximize growth performance. The indispensable AA requirements in ideal protein are usually expressed relative to the requirement of Lys (National Research Council, 1994; Mack et al., 1999; Wu, 2014). However, contrary to what is classically observed in pigs (Gloaguen et al., 2014), broiler performance is not maintained systematically when the CP content in the diet is reduced, even when the indispensable AA requirements are apparently met (Aletor et al., 2000; Bregendahl et al., 2002; Dean et al., 2006). These findings raise the question of the adequacy of $A A$ provision, and also whether a requirement for indispensable $A A$ or nonindispensable AA such as glycine and its precursors should be met (Dean et al., 2006, Siegert et al., 2015 and 2016). Moreover, few studies have been performed during the growing-finishing period (from 21 days of age) whereas this stage of production corresponds to $>75 \%$ of total feed intake and is the most important in terms of economic (feed cost) and environmental impact (e.g. nitrogen excretion), and the consequences of a reduction in dietary $\mathrm{CP}$ content on meat quality are rarely documented. Therefore, the aim of the experiments presented here was to evaluate the effects of reducing the dietary $\mathrm{CP}$ content in growing-finishing broilers on animal performance, carcass composition, meat quality and nitrogen utilization (i.e. body retention, excretion and volatilization).

\section{Material and methods}

Two successive dose response studies were performed. Experimental procedures and animal care were carried out according to current French legislation and under Authorizations 004601 and 006865 granted to S. T. and H. J., respectively, by the French Ministry of Agriculture, Agrifood and Forestry.

\section{Animals, experimental design and diets}

A total of 3000 (experiment 1) and 2000 (experiment 2) 1-day-old Ross PM3 male chicks were reared together on sawdust in an experimental poultry unit from days 1 to 20 (INRA EASM, Le Magneraud, France for experiment 1 and INRA PEAT, Nouzilly, France for experiment 2). Broilers were fed the same starter and grower diets (Supplementary Table S1). They were wing-tagged individually at day 7. At day 21, before the experimental period, they were weighed. Among broilers with similar BW (i.e. within 1 SD), 1520 and 912 were randomly distributed in 40 and 24 pens of $3 \mathrm{~m}^{2}$ (experiments 1 and 2, respectively), provided with sawdust (38 broilers/pen; 8 pens/treatment; $12 \mathrm{~kg}$ sawdust/pen). The average BW of the selected broilers was the same in both experiments $(945 \pm 90 \mathrm{~g})$. The ambient temperature programme applied was $31^{\circ} \mathrm{C}$ from days 0 to $3,29^{\circ} \mathrm{C}$ from days 4 to $6,28^{\circ} \mathrm{C}$ from days 7 to $13,26^{\circ} \mathrm{C}$ from days 14 to $20,24^{\circ} \mathrm{C}$ from days 21 to $24,22^{\circ} \mathrm{C}$ from days 25 to 27 and $20^{\circ} \mathrm{C}$ from day 28 until the end of the experiment. The lighting schedule was of $23 \mathrm{~h}$ of light from days 0 to 3 and of $18 \mathrm{~h}$ of light from days 4 to 31 . During the whole experiment, broilers had free access to water and feed. From days 21 to 35 (i.e. the experimental period), broilers were offered one of the experimental pelleted diets shown in Table 1. In both experiments, the experimental diets (Table 1) provided 13.2 MJ ME/kg and were sub-limiting in digestible Lys (dLys) at $0.9 \%$ (to be certain that the variations in measured responses are only due to the changes in dietary CP content). In each diet, the actual digestible $A A(\mathrm{dAA})$ to dLys ratios were equal or above the ratios proposed by Mack et al. (1999), except for Arg and Thr. The minimum dArg:dLys ratio was 108\% (instead of $112 \%$ ) and the minimum dThr:dLys ratio was $68 \%$ (instead of $63 \%$ ) based on recent literature data (Rostagno et al., 2011; Wu, 2014) and on results from a previous experiment showing that feed conversion ratio (FCR) could possibly be altered when decreasing the CP content (Supplementary Tables S2 and S3). Indeed, the dThr:dLys ratio proposed by Mack et al. (1999) was low in comparison with the recent recommendations. This is particularly important in low CP diets because the concentration of the dispensable AA Gly is reduced and, without Gly supplementation, additional Thr as a precursor of Gly may be required (Dean et al., 2006; Siegert et al., 2015 and 2016). The actual ratios of dArg:dLys and dThr:dLys in the experimental diets were therefore equal or above these new ratios (Table 1).

For both experiments, the same feedstuff batches were used and analysed before formulation by Ajinomoto Eurolysine S.A.S for total AA contents (Supplementary Table S4). From these analyses, and using digestibility values of $A A$ taken from Sauvant et al. (2004), dAA content of feedstuffs were calculated, and were used to formulate the experimental diets. In experiment 1, only the two extreme diets were formulated using linear programming to obtain 19\% and $15 \%$ CP. The three intermediary diets (i.e. 18\%, 17\% and $16 \% \mathrm{CP}$ ) were obtained by blending these diets at different proportions $(75: 25,50: 50$ and $25: 75$ for the $18 \%, 17 \%$ and $16 \%$ CP diets, respectively; Table 1). In experiment 2, the three experimental diets were formulated using linear programming to reach $19 \%, 17.5 \%$ and $16 \% \mathrm{CP}$, respectively (Table 1). Due to these differences in formulation strategy, the intermediary diets in experiment 1 contained the whole range of added feed-grade $A A$ and a higher inclusion of these AA compared with experiment 2 . As a result, some dAA concentrations were lower in the $17.5 \%$ and $16 \% \mathrm{CP}$ diets of experiment 2 compared with the $17 \%$ and $16 \%$ CP diets of experiment 1 . Moreover, Arg, Trp and lle ratios to Lys in the intermediate diets of experiment 1 were above the levels recommended by the adjusted ideal AA profile of Mack et al. (1999). 
Table 1 Feedstuffs and chemical composition (\%) of the diets differing in CP contents fed to broilers between 21 and 35 days of age

\begin{tabular}{|c|c|c|c|c|c|c|c|c|}
\hline \multirow[b]{2}{*}{ Diets } & \multicolumn{5}{|c|}{ Experiment 1} & \multicolumn{3}{|c|}{ Experiment 2} \\
\hline & CP19\% & CP18\% & CP17\% & CP16\% & CP15\% & CP19\% & CP17.5\% & CP16\% \\
\hline \multicolumn{9}{|l|}{ Feedstuffs } \\
\hline Maize & 43.4 & 47.2 & 51.1 & 54.9 & 58.7 & 43.4 & 48.4 & 54.6 \\
\hline Soyabean meal & 28.2 & 24.6 & 21.1 & 17.5 & 13.9 & 28.2 & 23.7 & 17.8 \\
\hline Wheat & 20.0 & 20.0 & 20.0 & 20.0 & 20.0 & 20.0 & 20.0 & 20.0 \\
\hline Soyabean oil & 4.9 & 4.2 & 3.6 & 2.9 & 2.2 & 4.9 & 4.1 & 3.0 \\
\hline Dicalcium phosphate & 1.7 & 1.7 & 1.7 & 1.7 & 1.7 & 1.7 & 1.7 & 1.7 \\
\hline Calcium carbonate & 0.80 & 0.80 & 0.80 & 0.80 & 0.80 & 0.77 & 0.79 & 0.83 \\
\hline Elancoban 200 & 0.05 & 0.05 & 0.05 & 0.05 & 0.05 & 0.05 & 0.05 & 0.05 \\
\hline Mineral-Vitamin premix ${ }^{1}$ & 0.80 & 0.80 & 0.80 & 0.80 & 0.80 & 0.80 & 0.80 & 0.80 \\
\hline DL-Methionine & 0.17 & 0.19 & 0.22 & 0.25 & 0.28 & 0.17 & 0.20 & 0.25 \\
\hline L-Lysine-HCl & 0.05 & 0.16 & 0.27 & 0.37 & 0.48 & 0.05 & 0.18 & 0.36 \\
\hline L-Threonine & 0.01 & 0.06 & 0.11 & 0.15 & 0.20 & 0.01 & 0.07 & 0.15 \\
\hline L-Arginine & - & 0.08 & 0.17 & 0.25 & 0.33 & - & 0.005 & 0.20 \\
\hline L-Valine & - & 0.04 & 0.09 & 0.13 & 0.18 & - & 0.02 & 0.11 \\
\hline L-Isoleucine & - & 0.04 & 0.08 & 0.13 & 0.17 & - & 0.006 & 0.10 \\
\hline L-Tryptophan & - & 0.01 & 0.02 & 0.03 & 0.04 & - & - & 0.02 \\
\hline \multicolumn{9}{|l|}{ Calculated composition } \\
\hline AMEn (MJ/kg) & 13.2 & 13.2 & 13.2 & 13.2 & 13.2 & 13.2 & 13.2 & 13.2 \\
\hline $\mathrm{CP}$ & 19.0 & 18.0 & 17.0 & 16.0 & 15.0 & 19.0 & 17.5 & 16.0 \\
\hline Calcium & 1.00 & 1.00 & 1.00 & 1.00 & 1.00 & 1.00 & 1.00 & 1.00 \\
\hline Available phosphorus² & 0.40 & 0.40 & 0.40 & 0.40 & 0.40 & 0.40 & 0.40 & 0.40 \\
\hline \multicolumn{9}{|c|}{ Calculated digestible AA values ${ }^{3}$} \\
\hline dLys & 0.90 & 0.90 & 0.90 & 0.90 & 0.90 & 0.90 & 0.90 & 0.90 \\
\hline dMet & 0.41 & 0.42 & 0.43 & 0.45 & 0.46 & 0.41 & 0.42 & 0.45 \\
\hline dMet + Cys & 0.67 & 0.67 & 0.67 & 0.67 & 0.67 & 0.67 & 0.67 & 0.67 \\
\hline dThr & 0.61 & 0.61 & 0.61 & 0.61 & 0.61 & 0.61 & 0.61 & 0.61 \\
\hline dVal & 0.78 & 0.77 & 0.76 & 0.74 & 0.73 & 0.78 & 0.73 & 0.73 \\
\hline dlle & 0.71 & 0.69 & 0.67 & 0.66 & 0.64 & 0.71 & 0.64 & 0.64 \\
\hline dLeu & 1.42 & 1.34 & 1.26 & 1.18 & 1.10 & 1.42 & 1.32 & 1.19 \\
\hline dTrp & 0.20 & 0.19 & 0.19 & 0.18 & 0.17 & 0.20 & 0.18 & 0.17 \\
\hline dArg & 1.09 & 1.06 & 1.03 & 1.00 & 0.97 & 1.09 & 0.97 & 0.97 \\
\hline dPhe & 0.85 & 0.79 & 0.72 & 0.66 & 0.59 & 0.85 & 0.77 & 0.66 \\
\hline dTyr & 0.61 & 0.57 & 0.52 & 0.47 & 0.42 & 0.61 & 0.55 & 0.48 \\
\hline dPhe + Tyr & 1.46 & 1.36 & 1.24 & 1.13 & 1.01 & 1.46 & 1.32 & 1.14 \\
\hline $\mathrm{dHis}$ & 0.45 & 0.42 & 0.38 & 0.35 & 0.32 & 0.45 & 0.41 & 0.36 \\
\hline dSer & 0.82 & 0.76 & 0.70 & 0.64 & 0.57 & 0.82 & 0.75 & 0.64 \\
\hline dGly & 0.66 & 0.61 & 0.56 & 0.51 & 0.46 & 0.66 & 0.59 & 0.51 \\
\hline dSer + Gly & 1.48 & 1.37 & 1.26 & 1.15 & 1.03 & 1.48 & 1.34 & 1.15 \\
\hline \multicolumn{9}{|c|}{ Calculated digestible AA ratio (\% of dLys) ${ }^{4}$} \\
\hline dMet & 45 & 47 & 48 & 50 & 51 & 45 & 47 & 50 \\
\hline $\mathrm{dMet}+$ Cys & 75 & 75 & 75 & 75 & 75 & 75 & 75 & 75 \\
\hline dThr & 68 & 68 & 68 & 68 & 68 & 68 & 68 & 68 \\
\hline $\mathrm{dVal}$ & 87 & 86 & 84 & 83 & 81 & 87 & 81 & 81 \\
\hline dlle & 79 & 77 & 75 & 73 & 71 & 79 & 71 & 71 \\
\hline dLeu & 158 & 149 & 140 & 131 & 122 & 158 & 147 & 132 \\
\hline dTrp & 23 & 22 & 21 & 20 & 19 & 23 & 20 & 19 \\
\hline dArg & 121 & 118 & 115 & 111 & 108 & 121 & 108 & 108 \\
\hline dPhe & 95 & 88 & 80 & 73 & 66 & 95 & 86 & 74 \\
\hline dTyr & 68 & 63 & 58 & 52 & 47 & 68 & 62 & 53 \\
\hline dPhe + Tyr & 163 & 151 & 138 & 125 & 113 & 163 & 148 & 127 \\
\hline $\mathrm{dHis}$ & 50 & 46 & 43 & 39 & 36 & 50 & 45 & 40 \\
\hline dSer & 92 & 85 & 78 & 71 & 64 & 92 & 83 & 71 \\
\hline dGly & 73 & 67 & 62 & 56 & 51 & 73 & 66 & 57 \\
\hline dSer + Gly & 165 & 152 & 140 & 127 & 115 & 165 & 149 & 128 \\
\hline
\end{tabular}

AA, amino acids.

${ }^{1}$ Supplied per kilogram of diet: $\mathrm{NaCl}=3 \mathrm{~g} ; \mathrm{Co}=0.6 \mathrm{mg} ; \mathrm{Cu}=20 \mathrm{mg} ; \mathrm{Fe}=58 \mathrm{mg} ; \mathrm{I}=2 \mathrm{mg} ; \mathrm{Mn}=80 \mathrm{mg} ; \mathrm{Se}=0.2 \mathrm{mg} ; \mathrm{Zn}=90 \mathrm{mg} ;$ retinyl acetate $=15000 \mathrm{IU}$; cholecalciferol $=4300 \mathrm{IU}$; $\mathrm{DL}-\alpha$ tocopheryl acetate $=100 \mathrm{mg}$; thiamine mononitrate $=5 \mathrm{mg}$; riboflavin $=8 \mathrm{mg}$; calcium pantothenate $=25 \mathrm{mg}$; cyanocobalamin $=$ $0.02 \mathrm{mg} ;$ menadione $=5 \mathrm{mg} ;$ pyridoxine hydrochloride $=7 \mathrm{mg} ;$ folic acid $=3 \mathrm{mg} ;$ biotin $=0.3 \mathrm{mg} ;$ niacin $=100 \mathrm{mg} ;$ choline chloride $=550 \mathrm{mg} ;$ antioxidant (buthylhydroxyanisole, propyl gallat, ethoxyquin) $=50 \mathrm{mg}$.

${ }^{2}$ Available phosphorus was calculated from total phosphorus in feedstuffs and availability coefficients from Sauvant et al. (2004).

${ }^{3}$ Digestible AA content was calculated from the total AA feedstuff content (chemical analyses) using digestibility coefficients from Sauvant et al. (2004).

${ }^{4}$ In all diets, AA:Lys ratios were equal or above the ratios proposed by Mack et al. (1999): dMet + Cys:Lys = 75\%, dVal:dLys = 81\%, dlle:dLys =71\% and dTrp:

$\mathrm{dLys}=112 \%$. For Thr and Arg, the minimum ratios were dThr:dLys $=68 \%$ and $\mathrm{dArg}: \mathrm{dLys}=108 \%$. 


\section{Animal performance, carcass characteristics and meat quality traits}

Total feed intake (g) over the experimental period was measured per pen. At the end of the experiment, all broilers were weighed individually after $6 \mathrm{~h}$ of fasting. Average BW (g) and BW gain $(\mathrm{g})$ were calculated for each pen. Feed conversion ratio was calculated for the experimental period from feed intake and BW gain. Four broilers per pen, representative of the average BW in the pen, were selected and slaughtered ( 32 broilers/treatment) in an experimental slaughter house. Broilers were electrically stunned in a water bath and then killed by ventral neck cutting. After partial evisceration (only the gut was removed), whole carcasses were air-chilled and stored at $2^{\circ} \mathrm{C}$ until the next day. Carcasses, abdominal fat and the left Pectoralis muscles ( $P$. major and $P$. minor) were weighed and total breast meat weight was calculated $((P$. major $+P$. minor $) \times 2)$. Abdominal fat and breast meat yield were expressed as a percentage of $\mathrm{BW}$.

In experiment 2, the ultimate $\mathrm{pH}$ of the $P$. major muscle was measured at $24 \mathrm{~h}$ postmortem with a portable $\mathrm{pH}$ meter (model 506; Crison Instruments SA, Alella, Barcelona, Spain) by inserting a glass electrode directly into the thickest part of the muscle. Breast colour was measured on the cranial ventral side of the muscle using a Miniscan spectrocolorimeter (HunterLab, Reston, VA, USA), and using the CIE LAB (international convention defined by $\mathrm{CIE}$, Vienna, Austria) trichromatic system for lightness $\left(L^{*}\right)$ values. After being weighed at $24 \mathrm{~h}$ postmortem, the $P$. major muscle was placed in a hanging plastic bag and stored at $2{ }^{\circ} \mathrm{C}$ for $96 \mathrm{~h}$. After hanging, the sample was wiped with absorbent paper and weighed again. The difference in weight corresponded to the drip loss and was expressed as the percentage of the initial muscle weight.

\section{Nitrogen utilization}

For each pen ( $n=8 /$ treatment), total nitrogen intake $\left(\mathrm{N}_{\text {intake }}, \mathrm{g}\right)$ was calculated by multiplying total feed intake (FI) of the pen by CP content of the diet and divided by 6.25 (equation (1)). Whole-body nitrogen retention $\left(\mathrm{N}_{\text {ret, }}, \mathrm{g}\right.$ ) was estimated according to equation (2) by multiplying the total BW gain of the pen by a constant value for whole-body nitrogen content $\left(\mathrm{N}_{\text {body }}=29 \mathrm{~g} / \mathrm{kg}\right.$; ITAVI, 2013) in agreement with previous studies (Aletor et al., 2000; Bregendahl et al., 2002) which showed that whole-body nitrogen content was not affected by a reduction in dietary CP content, even when dietary CP is limiting. The efficiency of nitrogen retention ( $\mathrm{N}_{\text {effi, }} \%$ ) was calculated using equation (3). Total excretion of nitrogen ( $\mathrm{N}_{\mathrm{exc}}, \mathrm{g}$ ) was calculated according to the difference between $N_{\text {intake }}$ and $N_{\text {ret }}$ (equation (4)) and was also expressed per $\mathrm{kg}$ of BW gain using equation (5) ( $N_{\text {exc_BWG, }} / \mathrm{kg}$ BW gain) to allow comparison between treatments and experiments:

$$
\begin{gathered}
N_{\text {intake }}=\mathrm{Fl} \times \mathrm{CP}_{\text {diet }} / 6.25 \\
\mathrm{~N}_{\text {ret }}=\mathrm{N}_{\text {body }} \times(\mathrm{BW} \text { gain } / 1000) \\
\mathrm{N}_{\text {effi }}=100 \times \mathrm{N}_{\text {ret }} / \mathrm{N}_{\text {intake }}
\end{gathered}
$$

$$
\begin{aligned}
N_{\text {exc }} & =N_{\text {intake }}-N_{\text {ret }} \\
N_{\text {exc_BWG }} & =N_{\text {exc }} / \text { BW gain }
\end{aligned}
$$

A sample of sawdust was collected before the experimental period, frozen and stored at $-20^{\circ} \mathrm{C}$. At day 35 , four pens per treatment in each experiment were randomly selected. For those pens, total manure was removed and weighed (after broiler withdrawal), from which a sample of $1500 \mathrm{~g}$ was taken by mixing all the manure. During the experiments, no extra sawdust was added and no manure was removed. To stop all gaseous emissions from the manure, manure samples were frozen and stored at $-20^{\circ} \mathrm{C}$. Total nitrogen loss $\left(\mathrm{N}_{\text {loss, }} \mathrm{g}\right)$ through gas emissions was estimated for these pens using equation (6), $\mathrm{W}_{\text {manure }}$ being the total weight of the manure produced in the pen $(\mathrm{kg}), \mathrm{N}_{\text {manure }}$ the nitrogen content of the manure $(\mathrm{g} / \mathrm{kg}), W_{\text {sawdust }}$ the weight of sawdust used as bedding material $\left(\mathrm{W}_{\text {sawdust }}=12 \mathrm{~kg} / \mathrm{pen}\right)$ and $\mathrm{N}_{\text {sawdust }}$ the nitrogen content of the sawdust $(\mathrm{g} / \mathrm{kg})$. The nitrogen volatilization rate $\left(\mathrm{N}_{\mathrm{vol}}, \%\right)$ was calculated using equation (7) and expressed as a percentage of total $\mathrm{N}$ excretion:

$$
\begin{gathered}
N_{\text {loss }}=N_{\text {exc }}-\left(W_{\text {manure }} \times N_{\text {manure }}-W_{\text {sawdust }} \times N_{\text {sawdust }}\right) \\
N_{\text {vol }}=100 \times\left(N_{\text {loss }} / N_{\text {exc }}\right)
\end{gathered}
$$

\section{Chemical analyses}

Samples of the main feed ingredients and diets, sawdust and manure were analysed for dry matter (DM) (AFNOR method V18-109), nitrogen (Kjedahl method, ISO 1871) and AA content (only for the feed ingredients and diets, ISO 13903) by Ajinomoto Eurolysine S.A.S. Customers Laboratory (Amiens, France). The analysed values for nitrogen and $A A$ content of the experimental diets (Supplementary Table S4) were consistent with expected values.

\section{Statistical Analyses}

One-way ANOVA was performed using the GLM procedure of SAS (SAS Institute Inc., Cary, NC, USA) for BW, feed intake, BW gain, FCR, breast meat yield, abdominal fat (both experiments) and ultimate $\mathrm{pH}$, lightness and drip loss (experiment 2). For BW, BW gain, feed intake and FCR the statistical unit was the pen ( $n=8 /$ treatment). For breast meat yield, abdominal fat, ultimate $\mathrm{pH}$, lightness and drip loss, the statistical unit was the animal ( $n=32 /$ treatment). Normality of data was assessed using the Shapiro-Wilk test and the hypothesis for a normal distribution of the data was not rejected. Differences between treatments were tested and significance was accepted at $P<0.05$.

The relationships between $\mathrm{N}_{\text {effi, }} \mathrm{N}_{\text {exc_BW, }}, \mathrm{N}_{\text {vol, }}$, nitrogen and moisture (i.e. $100-D M$ ) contents in the manure content $v$. CP content of the experimental diet were evaluated using linear regressions (R software v. 3.2.3; R Core Team, Vienna, Austria). In experiment 1 , regression methods (i.e. linear, quadratic, linear plateau and curvilinear plateau models) were also used to model the effects of $\mathrm{CP}$ on animal 
performance and carcass characteristics using the REG procedures of SAS.

\section{Results}

\section{Animal responses and consequences on carcass and meat quality traits}

In experiment 1 , reducing the dietary CP content from 19\% to $15 \%$ did not alter BW, BW gain or feed intake, in contrast to FCR $(P<0.01$; Table 2$)$. The FCR was significantly higher in the $16 \%$ and $15 \%$ CP diets compared with the other three diets. The breast meat yield was not affected by the dietary $C P$. The percentage of abdominal fat was increased by the reduction in dietary $C P$ content $(P<0.01)$, the highest values being observed for the $16 \%$ and $15 \%$ CP diets (Table 2). Only a linear relation between FCR and $\mathrm{CP}$ was found to be significant $\left(\mathrm{FCR}=1.95-0.017 \times C P ; R^{2}=0.53 ; P<0.001\right)$.

As shown in Table 3, no significant effect of dietary CP on animal performance (i.e. BW, BW gain, feed intake and FCR) was observed in experiment 2, even though a tendency was observed for feed intake $(P=0.053)$. The percentage of abdominal fat was significantly increased $(P=0.02)$ when decreasing $C P$ content but with no effect on breast meat yield $(P=0.06)$. The dietary CP decrease also had significant effects on meat quality traits with an increase in ultimate $\mathrm{pH}$ and a decrease of meat lightness and drip loss $(P<0.001$ for both ultimate $\mathrm{pH}$ and $L^{*}$, and $P=0.045$ for drip loss).

\section{Nitrogen utilization and manure composition}

The evolution of estimate efficiency of nitrogen retention, nitrogen excretion, nitrogen and moisture contents in the manure, and nitrogen volatilization with dietary CP content are given in Figure $1 a, b, 2 a$ and $b$, respectively. The efficiency of nitrogen retention increased from $+3.2 \%$ to $+3.6 \% / C P$ percentage point when dietary CP content was reduced (Figure 1a). Nitrogen excretion per kg of BW gain decreased with reduced CP content (Figure $1 \mathrm{~b}$ ), from 2.1 to $2.9 \mathrm{~g} / \mathrm{kg} \mathrm{BW}$ gain/CP percentage point (Figure $1 \mathrm{~b}$ ). The analytical results of manure composition are presented in
Figure 2a. Nitrogen and moisture content decreased slightly when the dietary CP content was reduced. The calculated nitrogen volatilization also decreased when dietary $C P$ content was reduced $(-3.9$ to -6.4 points/CP percentage point; Figure 2b).

\section{Discussion}

To investigate the effects of reducing the dietary CP content in broiler feed, two successive experiments were performed. Using an adjusted AA profile to test the response to the decrease in dietary $C P$, no significant effect was found between treatments for BW, BW gain and feed intake in experiment 1, while FCR was maintained until 17\% CP and increased below this level. In experiment 2, reducing the dietary $\mathrm{CP}$ content did not affect $\mathrm{FCR}$, even with $16 \% \mathrm{CP}$. This means that implementing the adjusted ideal AA profile of Mack et al. (1999) with changes in dArg:dLys and dThr: dLys ratios allows to decrease the CP content by 2 to 3 percentage points in broiler diets without impairing performance. These findings contradict the decrease in BW gain and feed efficiency frequently described in the literature (Alleman and Leclercq, 1997; Bregendahl et al., 2002; Dean et al., 2006), even though the indispensable AA requirements, in these studies, were apparently met. This negative effect on performance was also reported in a meta-analysis modelling the responses of BW gain and feed efficiency on dietary CP content (Pesti, 2009). In the present study, BW gain was unchanged and the negative impact of the reduction in CP content on FCR was found to be lower than in this meta-analysis $(-0.017 v$. -0.033 per $1 \% \mathrm{CP})$. The improvement in feed efficiency by genetic selection of broilers during this last decade could be an explanation to this difference, as Pesti's study was based on trials performed before 2007. The reduction in dietary $C P$ content tended to result in an increase in feed intake in experiment $2(P=0.053)$. One hypothesis might be that the reduction of dietary $C P$ is associated with a reduction of some indispensable AA such as Leu that, when provided in excess, are known to limit

Table 2 Performance and carcass characteristics of Ross PM3 male broilers fed with diets differing in CP between 21 and 35 days of age (experiment 1)

\begin{tabular}{|c|c|c|c|c|c|c|c|}
\hline & \multicolumn{5}{|c|}{ Diets } & \multirow[b]{2}{*}{ SEM } & \multirow[b]{2}{*}{$P$-value } \\
\hline & CP19\% & CP18\% & CP17\% & CP16\% & CP15\% & & \\
\hline \multicolumn{8}{|l|}{ Performance $^{1}$} \\
\hline BW at day 35 (g) & 2460 & 2470 & 2466 & 2451 & 2461 & 10.6 & 0.99 \\
\hline BW gain $(g)$ & 1479 & 1496 & 1494 & 1446 & 1478 & 12.1 & 0.72 \\
\hline Feed intake (g) & 2430 & 2477 & 2472 & 2459 & 2528 & 16.9 & 0.48 \\
\hline Feed conversion ratio & $1.64^{b}$ & $1.65^{\mathrm{b}}$ & $1.65^{b}$ & $1.69^{\mathrm{a}}$ & $1.71^{\mathrm{a}}$ & 0.01 & $<0.01$ \\
\hline \multicolumn{8}{|l|}{ Carcass characteristics $^{2}$} \\
\hline Breast meat yield ( $\%$ of BW) & 20.1 & 20.2 & 20.8 & 20.5 & 19.5 & 0.15 & 0.08 \\
\hline Abdominal fat (\% of BW) & $2.16^{\mathrm{b}}$ & $2.30^{\mathrm{ab}}$ & $2.45^{\mathrm{a}}$ & $2.61^{\mathrm{a}}$ & $2.51^{\mathrm{a}}$ & 0.04 & $<0.01$ \\
\hline
\end{tabular}

${ }^{1} n=8 /$ treatment.

${ }^{2} n=32 /$ treatment

a,b Values within a row with different superscripts differ significantly at $P<0.05$. 
Belloir, Méda, Lambert, Corrent, Juin, Lessire and Tesseraud

Table 3 Performance, carcass characteristics and meat quality traits of Ross PM3 male broilers fed with diets differing in CP contents between 21 and 35 days of age (experiment 2)

\begin{tabular}{|c|c|c|c|c|c|}
\hline & \multicolumn{3}{|c|}{ Diets } & \multirow[b]{2}{*}{ SEM } & \multirow[b]{2}{*}{$P$-value } \\
\hline & CP19\% & CP17.5\% & CP16\% & & \\
\hline \multicolumn{6}{|l|}{ Performance $^{1}$} \\
\hline BW at day $35(\mathrm{~g})$ & 2288 & 2332 & 2324 & 12.4 & 0.32 \\
\hline BW gain $(\mathrm{g})$ & 1338 & 1380 & 1374 & 12.1 & 0.32 \\
\hline Feed intake $(\mathrm{g})$ & 2242 & 2323 & 2348 & 19.1 & 0.053 \\
\hline Feed conversion ratio & 1.68 & 1.68 & 1.71 & 0.01 & 0.17 \\
\hline \multicolumn{6}{|l|}{ Carcass characteristics $^{2}$} \\
\hline Breast meat yield (\% of BW) & 20.8 & 20.9 & 21.4 & 0.10 & 0.06 \\
\hline Abdominal fat ( $\%$ of BW) & $1.93^{b}$ & $2.09^{\mathrm{ab}}$ & $2.15^{a}$ & 0.04 & 0.02 \\
\hline \multicolumn{6}{|l|}{ Meat quality traits ${ }^{2}$} \\
\hline Ultimate $\mathrm{pH}$ & $5.92^{c}$ & $6.04^{b}$ & $6.14^{\mathrm{a}}$ & 0.02 & $<0.001$ \\
\hline Lightness & $51.6^{\mathrm{a}}$ & $49.5^{\mathrm{b}}$ & $46.3^{c}$ & 0.30 & $<0.001$ \\
\hline Drip loss (\%) & $3.07^{\mathrm{a}}$ & $2.53^{\mathrm{ab}}$ & $2.33^{\mathrm{b}}$ & 0.13 & 0.045 \\
\hline
\end{tabular}

${ }^{1} n=8$ /treatment.

${ }^{2} n=32 /$ treatment.

$a, b, c$ Values within a row with different superscripts differ significantly at $P<0.05$.

(a)

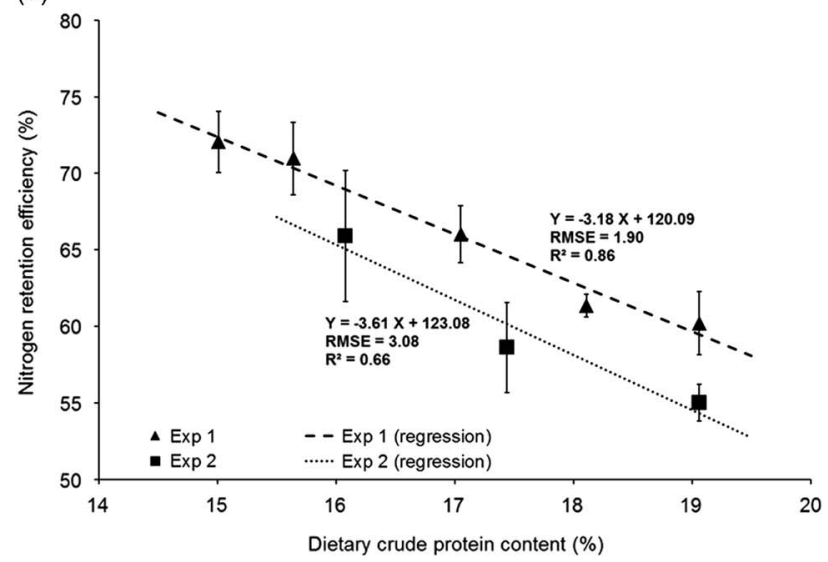

(b)

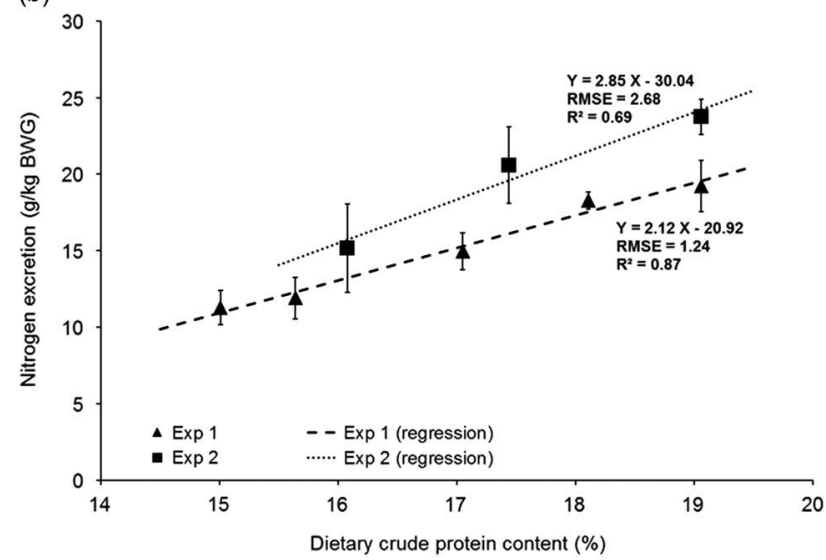

Figure 1 Nitrogen utilization in male Ross PM3 broilers according to the dietary $C P$ content. Average values $( \pm S D)$ of (a) the efficiency of nitrogen utilization ( $\mathrm{N}_{\text {effi, }}$ equation (3)) and (b) nitrogen excretion $\left(\mathrm{N}_{\text {exc } B W G}\right.$, equation (4)). Linear regressions were fitted with pen values ( $n=8 /$ treatment).

ingestion in various species including pigs (Gloaguen et al., 2012). Another explanation might be that broilers consumed more feed because they needed more protein to attain their
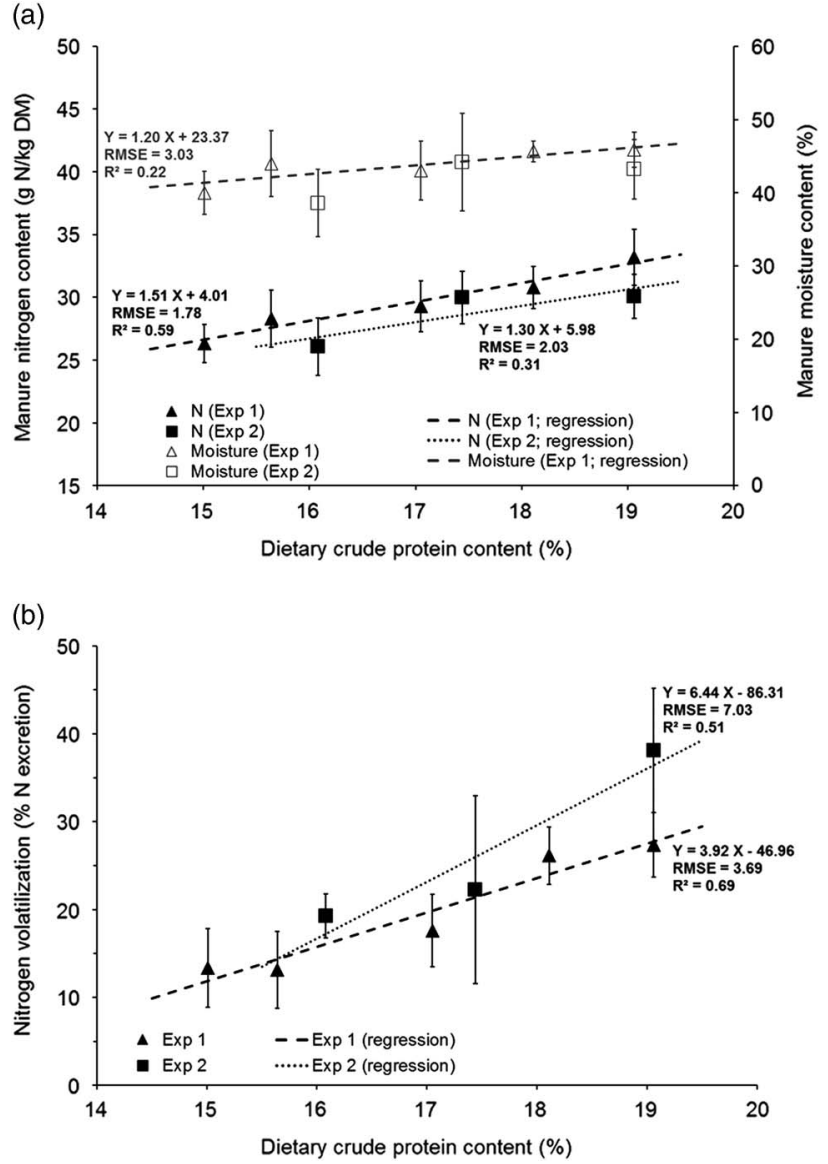

Figure 2 Manure composition and calculated nitrogen volatilization according to the dietary $\mathrm{CP}$ content. Average $( \pm S D)$ values of (a) nitrogen and moisture content of manure and (b) total nitrogen volatilization $\left(\mathrm{N}_{\mathrm{vol}}\right.$ equation (7)). Linear regressions were fitted with pen values $(n=4 /$ treatment). For manure moisture in experiment 2 , coefficients of the linear regression were not significantly different from 0 .

genetic potential according to the theory of feed intake and growth proposed by Emmans (1987). Nevertheless, more recent findings reported by Gous (2007) did not fully confirm 
$\mathrm{CP}$ reduction in broiler diets

Table 4 Linear regressions of nitrogen retention efficiency ( $\left.N_{\text {effi }}\right)$ and nitrogen excretion ( $\left.N_{\text {exc } \_ \text {BWG }}\right)$ v. CP content from data published in the literature

\begin{tabular}{|c|c|c|c|c|c|c|c|c|c|c|c|}
\hline \multirow[b]{2}{*}{ References } & \multirow[b]{2}{*}{ Experiment } & \multirow[b]{2}{*}{$\mathrm{CP}$ range } & \multirow{2}{*}{$\begin{array}{c}\text { Age of } \\
\text { broilers (days) }\end{array}$} & \multicolumn{4}{|c|}{$\mathrm{N}_{\text {effi }}$} & \multicolumn{4}{|c|}{$\mathrm{N}_{\text {exc_BWG }}$} \\
\hline & & & & Slope & Intercept & RMSE & $R^{2}$ & Slope & Intercept & RMSE & $R^{2}$ \\
\hline Bregendahl et al. (2002) & 1 & 23.5 to 19 & 7 to 21 & -1.50 & 86.77 & 0.49 & 0.96 & 1.34 & -6.89 & 0.29 & 0.98 \\
\hline Bregendahl et al. (2002) & 2 & 24 to 18.5 & 7 to 21 & -1.23 & 84.51 & 1.19 & 0.78 & 1.14 & -4.61 & 0.27 & 0.98 \\
\hline Bregendahl et al. (2002) & 3 & 23.5 to 18.5 & 7 to 21 & -1.40 & 87.30 & 0.59 & 0.92 & 1.33 & -8.53 & 0.34 & 0.97 \\
\hline Aletor et al. (2000) & 1 & 22.5 to 16 & 21 to 42 & -2.02 & 92.92 & 1.57 & 0.87 & 1.90 & -9.70 & 1.74 & 0.83 \\
\hline Gomide et al. (2011) & 1 & 21 to 18 & 14 to 21 & -1.67 & 105.40 & 0.67 & 0.83 & 1.69 & -16.89 & 0.56 & 0.88 \\
\hline Gomide et al. (2011) & 2 & 20 to 17 & 28 to 35 & -1.44 & 92.55 & 0.63 & 0.80 & 2.04 & -16.34 & 0.77 & 0.85 \\
\hline
\end{tabular}

this theory since, instead of increasing feed intake as dietary $\mathrm{CP}$ content was reduced, some broiler genotypes reduced their feed intake. The possibility of broilers to adjust feed intake according to their genotype has implications for the optimization of feeding strategies. An increase in feed intake (without an increase in weight gain) would also partly explain the increase in abdominal fat such as the one we observed with low CP diets, the excess of energy being stored as fat.

This significant increase in abdominal fat with reduced CP content is in agreement with the literature, whereas the findings are more controversial for breast meat yield that remained unchanged (with a tendency for an increase) but decreased according to other studies (Alleman and Leclercq, 1997; Berres et al., 2010; Namroud et al., 2010). The increase in abdominal fat could here be explained by the increase of the dietary ME:CP ratio when reducing $\mathrm{CP}$ (Table 1). This suggests that the use of an adapted AA profile allows maximization of breast meat yield, at least until $16 \%$ CP. In addition, meat quality traits measured in experiment 2 were affected by the reduction in dietary $\mathrm{CP}$ content. It resulted in an increase in ultimate $\mathrm{pH}$ of breast meat. According to several authors, the ultimate $\mathrm{pH}$ is negatively correlated to the glycogen content of the muscle (Berri et al., 2008, Le Bihan-Duval et al., 2008). We assumed that the provision of a more balanced $A A$ profile (associated with the reduction in $C P$ content) reduced the excess of $A A$, decreasing the amount of nutrients available for glycogen production/storage through AA catabolism. Several studies have indeed shown that the ultimate $\mathrm{pH}$ responds to dietary treatments and in particular to variation in the Lys, Met or protein content (Berri et al., 2008; Jlali et al., 2012; Conde-Aguilera et al., 2016). Moreover, we showed that the increase in ultimate $\mathrm{pH}$ of breast meat was associated with a lower lightness and drip loss, in agreement with results from others (Berri et al., 2008; Le Bihan-Duval et al., 2008). Moreover, as the ultimate $\mathrm{pH}$ increased with decreasing $\mathrm{CP}$ content, one can expect an improvement in the processing ability of breast meat, in line poultry processors' expectations (Alnahhas et al., 2014).

The estimated nitrogen efficiency in the two experiments was improved by 3.2 to 3.6 percentage points/percentage point $\mathrm{CP}$ reduction. As shown in Table 4, these values are higher than those reported in the literature (up to +2 percentage points/percentage point CP reduction; Aletor et al., 2000;
Bregendahl et al., 2002; Gomide et al., 2011). Moreover, the efficiency of nitrogen retention for broilers that received diets with $<16 \%$ CP were above $70 \%$. Even though these values are extremely high and could be questioned, efficiencies $>70 \%$ have been reported in growing broilers (Siegert et al., 2016). Further investigations are required to evaluate the physiological limit to the increase in the efficiency of nitrogen utilization in relation to the maximum metabolic utilization of absorbed AA. Two hypotheses can be formulated to explain the higher nitrogen retention found in our study. First, due to an adequate AA profile in our experimental diets, BW gain was maintained whereas growth and FCR were negatively impacted in other studies. Second, the broilers used in our study may have been more efficient, due to the genetic selection for feed efficiency for over more than a decade.

The main consequence of the improvement of the efficiency of nitrogen utilization was the reduction in nitrogen excretion as shown in Figure $1 \mathrm{~b}$. As for $\mathrm{N}_{\text {effi, }}$ the reduction in excretion ( -2.1 to $-2.9 \mathrm{~g} / \mathrm{kg}$ BW gain) was higher in the present experiments than in previous studies (Table 4), which can be explained by a higher efficiency of nitrogen utilization found in our experiment. Between 19\% and 16\% CP, the reduction of one $C P$ percentage point decreased nitrogen excretion by $13 \%$ (Supplementary Table S5 for details on this calculation), while in the literature the decrease was closer to 10\% (Aletor et al., 2000; Bregendahl et al., 2002; Gomide et al., 2011). Moreover, reducing the dietary CP content decreased the nitrogen and moisture content of the manure, which also confirms previous reports on manure and fresh droppings (Ferguson et al., 1998; Si et al., 2004; Hernández et al., 2012). This reduction in moisture content may be due to a lower water intake and water excretion by broilers fed the low CP diets (Alleman and Leclercq, 1997; Hernández et al., 2012). In our experiments, the decrease in dietary CP was associated with a lower use of soyabean meal, which is very rich in potassium. A decreased potassium content in the diet can lead to a lower water intake (Alleman and Leclercq, 1997; Francesch and Brufau, 2004).

The observed decrease in manure moisture content could also explain the lower volatilization rate of excreted nitrogen in pens with broilers fed low CP diets ( -5 points/CP percentage point on average for the two experiments). The moisture content of manure is one of the main factors contributing to the microbial activity in manure, and thus in the 
transformation of excreted nitrogen into ammonia (Méda et al., 2011). This is in agreement with the work of Ferguson et al. (1998), who reported a decrease of moisture content and nitrogen volatilization in manure when the dietary $\mathrm{CP}$ content was reduced. As a consequence, the simultaneous decrease of nitrogen excretion and nitrogen volatilization percentage leads to strong and synergistic decrease of nitrogen amounts lost through volatilization by about $-30 \% / \mathrm{CP}$ percentage point (Supplementary Table S6 for details on this calculation).

\section{Conclusions}

In conclusion, the present findings clearly show that a reduction of the dietary CP content by several CP percentage points is possible in growing-finishing broilers with positive implications for the sustainability of broiler production. By using the ideal AA profile of Mack et al. (1999) modified for Arg and Thr, growth performance of modern growing-finishing broilers was not affected when the diets provided between $19 \%$ and $17 \%$ CP. Such a nutritional strategy also had a positive impact on meat quality traits with potential better processing abilities for breast meat, and on the environment with reduced nitrogen excretion and volatilization rates. In the future, other nutritional strategies have to be identified to achieve an even greater decrease in dietary CP (i.e. below 17\%). Also, the requirements for the next limiting AA (e.g. Val and Ile, and also non-indispensable AA such as Gly) should be assessed.

\section{Acknowledgements}

The authors thank Fréderic Mercerand and Nicolas Besne (INRA PEAT, Nouzilly, France), Philippe Rousseau (INRA EASM, Le Magneraud, France), Michel Couty, Jean-Marc Hallouis, Sabine Crochet, Thierry Bordeau and Estelle Cailleau-Audouin (INRA URA, Nouzilly, France) and Marcelle Eudaimon (Ajinomoto Eurolysine S.A.S. Customers Laboratory, Amiens, France) for their collaboration in this study. They are also grateful to Doreen Raine (Surrey, UK) for editing the English language. This study received financial support from INRA and Ajinomoto Eurolysine S.A.S.

\section{Supplementary material}

To view supplementary material for this article, please visit https://doi.org/10.1017/S1751731117000660

\section{References}

Aletor VA, Hamid II, Nieß E and Pfeffer E 2000. Low-protein amino acidsupplemented diets in broiler chickens: effects on performance, carcass characteristics, whole-body composition and efficiencies of nutrient utilisation. Journal of the Science of Food and Agriculture 80, 547-554.

Alleman F and Leclercq B 1997. Effect of dietary protein and environmental temperature on growth performance and water consumption of male broiler chickens. British Poultry Science 38, 607-610.

Alnahhas N, Berri $C$, Boulay $M$, Baéza $E$, Jégo $Y$, Baumard $Y$, Chabault $M$ and Le Bihan-Duval E 2014. Selecting broiler chickens for ultimate $\mathrm{pH}$ of breast muscle: analysis of divergent selection experiment and phenotypic consequences on meat quality, growth, and body composition traits. Journal of Animal Science 92, 3816-3824.

Berres J, Vieira SL, Dozier WA, Cortês MEM, de Barros R, Nogueira ET and Kutschenko M 2010. Broiler responses to reduced-protein diets supplemented with valine, isoleucine, glycine, and glutamic acid. Journal of Applied Poultry Research 19, 68-79.

Berri C, Besnard J and Relandeau C 2008. Increasing dietary lysine increases final $\mathrm{pH}$ and decreases drip loss of broiler breast meat. Poultry Science 87, 480-844.

Bouwman AF, Vuuren DPV, Derwent RG and Posch M 2002. A global analysis of acidification and eutrophication of terrestrial ecosystems. Water, Air, \& Soil Pollution 141, 349-382.

Bregendahl K, Sell JL and Zimmerman DR 2002. Effect of low-protein diets on growth performance and body composition of broiler chicks. Poultry Science 81, 1156-1167.

Conde-Aguilera JA, Cholet JCG, Lessire $M$, Mercier $Y$, Tesseraud $S$ and van Milgen J 2016. The level and source of free-methionine affect body composition and breast muscle traits in growing broilers. Poultry Science 95, 2322-2331.

Dean DW, Bidner TD and Southern LL 2006. Glycine supplementation to low protein, amino acid-supplemented diets supports optimal performance of broiler chicks. Poultry Science 85, 288-296.

de Vries M and de Boer IJM 2010. Comparing environmental impacts for livestock products: a review of life cycle assessments. Livestock Science 128, 1-11. Emmans GC 1987. Growth, body composition and feed intake. World's Poultry Science Journal 43, 208-227.

Ferguson NS, Gates RS, Taraba JL, Cantor AH, Pescatore AJ, Ford MJ and Burnham DJ 1998. The effect of dietary crude protein on growth, ammonia concentration and litter composition in broilers. Poultry Science 77, 1481-1487.

Francesch $M$ and Brufau J 2004. Nutritional factors affecting excreta/litter moisture and quality. World's Poultry Science Journal 60, 64-75.

Gerber PJ, Steinfeld H, Henderson B, Mottet A, Opio C, Dijkman J, Falcucci A and Tempio $G$ 2013. Tackling climate change through livestock. A global assessment of emissions and mitigation opportunities. Food and Agriculture Organization of the United Nations (FAO), Rome, Italy, 115pp.

Gloaguen M, Le Floc'h N, Corrent E, Primot $Y$ and van Milgen J 2012. Providing a diet deficient in valine but with excess leucine results in a rapid decrease in feed intake and modifies the postprandial plasma amino acid and $\alpha$-keto acid concentrations in pigs. Journal of Animal Science 90, 3135-3142.

Gloaguen M, Le Floc'h N, Corrent E, Primot Y and van Milgen J 2014. The use of free amino acids allows formulating very low crude protein diets for piglets. Journal of Animal Science 92, 637-644.

Gomide EM, Rodrigues PB, Zangeronimo MG, Bertechini AG, dos Santos LM and Alvarenga RR 2011. Nitrogen, calcium and phosphorus balance of broilers fed diets with phytase and crystalline amino acids. Ciência e Agrotecnologia 35, 591-597.

Gous RM 2007. Predicting nutrient responses in poultry: future challenges. Animal 1, 57-65.

Hernández F, López M, Martínez S, Megías MD, Catalá P and Madrid J 2012. Effect of low-protein diets and single sex on production performance, plasma metabolites, digestibility, and nitrogen excretion in 1- to 48-day-old broilers. Poultry Science 91, 683-692.

Institut Technique de l'Aviculture (ITAVI) 2013. Estimation des rejets d'azote, phosphore, potassium, calcium, cuivre, zinc par les élevages avicoles. Comité d'Orientation pour des Pratiques Agricoles Respectueuses de l'Environnement, Paris, France, 63pp. Jlali M, Gigaud V, Metayer-Coustard S, Sellier N, Tesseraud S, Le Bihan-Duval E and Berri C 2012. Modulation of glycogen and breast meat processing ability by nutrition in chickens: effect of crude protein level in 2 chicken genotypes. Journal of Animal Science 90, 447-455.

Le Bihan-Duval E, Debut M, Berri CM, Sellier N, Santé-Lhoutellier V, Jégo Y and Beaumont C 2008. Chicken meat quality: genetic variability and relationship with growth and muscle characteristics. BMC Genetics 9, 53.

Mack S, Bercovici D, De Groote G, Leclercq B, Lippens M, Pack M, Schutte JB and van Cauwenberghe $S$ 1999. Ideal amino acid profile and dietary lysine specification for broiler chickens of 20 to 40 days of age. British Poultry Science 40, 257-265.

Méda B, Hassouna M, Aubert C, Robin P and Dourmad JY 2011. Influence of rearing conditions and manure management practices on ammonia and greenhouse gas emissions from poultry houses. World's Poultry Science Journal $67,441-456$. 


\section{$\mathrm{CP}$ reduction in broiler diets}

Namroud NF, Shivazad M and Zaghari M 2010. Impact of dietary crude protein and amino acids status on performance and some excreta characteristics of broiler chicks during 10-28 days of age. Journal of Animal Physiology and Animal Nutrition 94, 280-286.

National Research Council 1994. Nutrient requirements of poultry, 9th revised edition. The National Academies Press, Washington, DC, USA. 176pp.

Pesti GM 2009. Impact of dietary amino acid and crude protein levels in broiler feeds on biological performance. Journal of Applied Poultry Research 18, 477-486.

Rostagno HS, Teixeira Albino LF, Donzele JL, Gomes PC, de Oliveira RF, Lopes DC, Ferreira AS, de Toledo Barreto SL and Euclides RF 2011. Tabelas Brasileiras para aves e suinos: Composição de Alimentos e Exigências Nutricionais, $3^{\mathrm{a}}$ Edição. Universidade Federal de Viçosa - Departamento de Zootecnia, Viçosa, Minas Gerais, Brazil, 252pp.

Sauvant D, Perez JM and Tran G 2004. Tables of composition and nutritional value of feed materials: pigs, poultry, cattle, sheep, goats, rabbits, horses, fish, 2nd edition. INRA, Paris, France. 304pp.
Si J, Fritts CA, Burnham DJ and Waldroup PW 2004. Extent to which crude protein may be reduced in corn-soybean meal broiler diets through amino acid supplementation. International Journal of Poultry Science 3, 46-50.

Siegert W, Ahmadi H, Helmbrecht A and Rodehutscord M 2015. A quantitative study of the interactive effects of glycine and serine with threonine and choline on growth performance in broilers. Poultry Science 94, 1557-1568.

Siegert W, Wild KJ, Schollenberger $\mathrm{M}$, Helmbrecht $\mathrm{A}$ and Rodenhutscord $\mathrm{M}$ 2016. Effect of glycine supplementation in low protein diets with amino acids from soy protein isolate or free amino acids on broiler growth and nitrogen utilisation. British Poultry Science 57, 424-434.

Steinfeld H, Gerber P, Wassenaar T, Castel V, Rosales M and de Haan C 2006. Livestock's long shadow. Environmental issues and options. FAO, Rome, Italy. 390pp. Wu G 2014. Dietary requirements of synthesizable amino acids by animals: a paradigm shift in protein nutrition. Journal of Animal Science and Biotechnology 5, 34. 